\title{
Clinical Profile of Injuries due to Paragliding Accident Attended in a Tertiary Hospital of Western Region of Nepal
}

\author{
Kandel IS ${ }^{1^{*}}$, Acharya $\mathrm{K}^{2}$, Gupta $\mathrm{S}^{3}$, Shrestha $\mathrm{B}^{1}$, Bista KB ${ }^{4}$, Dhakal RM ${ }^{4}$, Tripathi $\mathbf{N}^{4}$ \\ ${ }^{1}$ Associate Professor, ${ }^{4}$ Assistant professor, Department of Orthopaedic and Trauma surgery, \\ ${ }^{2}$ Associate Professor, ${ }^{3}$ Assistant professor, Department of General Practices and Emergency Medicine, \\ Gandaki Medical College \& Teaching Hospital, Pokhara, Nepal
}

\author{
Keywords \\ Accidents, Foot, Injury, Paragliding, Pokhara.

\section{Corresponding author} \\ *Dr. Ishwar Sharma Kandel, MS \\ Associate Professor, Department of Orthopedic \& \\ Trauma surgery, \\ Gandaki Medical College \& Teaching Hospital, \\ Pokhara, Nepal \\ E-mail:drisk79@gmail.com
}

\begin{abstract}
Introduction: Paragliding is an adventurous aerial sport which is performed regularly in and around Pokhara. The Western Region of Nepal (Especially Pokhara, Parbat, Baglung and Syanjya) is famous not only for its natural beauty but for adventurous sports like paragliding, ultraflight and bungee jumping etc. The growing popularity of paragliding sport has led to a steady increase in the number of associated injuries.
\end{abstract}

Objectives: The main objective of this retrospective review is to find out characteristic of injuries in different of paragliding accidents.

Methods: This is a retrospective review of paragliding injury cases who attended emmergency department of Gandaki Medical College, Pokhara, Nepal from June 2009 to May 2016. Demographic profile (Age, sex, address), type of flight, timing of accident, severity and pattern of injures were collected and analyzed using the frequency table.

Results: Among 60 people who faced accidents and brought to hospital, four of them with severe multiple trauma were declared dead in the emergency department at the time of arrival. Fifty six patients were injured with varieties of injury. Among 56 survived patients, 14 (25\%) were minor injuries and discharged from the Emergency Department after treatment for soft tissue trauma like abrasion or sprain. Twelve patients with polytrauma (Including four chest injury, two abdominal injury with multiple bone fractures) and rest of the patients were admitted and treated/reffered/discharged.

Conclusion: Lower limb especially foot and ankle injury were the commonest type of injury followed by spine fracture in paragliding accidents.

\section{INTRODUCTION}

Many studies are performed in different parts of world regarding causes and pattern of injures in paraglidng accident. Till now we don't have such studies performed in our setup.

The main objectives of this retrospective review was to find out the characteristic (Pattern and severity) of injuries in different paragliding accident cases who attended Emergency Department of Gandaki Medical College so that management protocol can be planned in hospital. This study also aimed to find out mode and timing of accident (Takeoff, lidair, landing) so that certain protective measure and precaution can be recommended to pilots and paragliding company to prevent and reduce number of accident in coming days. 


\section{METHODS}

This is a retrospective review of paragliding injury cases who attended Emergency Department of Gandaki Medical College, Pokhara, Nepal from June 2009 to May 2016. Demographic profile (Age, sex, address), type of flight, timing of accident, severity and pattern of injures were collected and analysed using the frequency table. Severity as minor (no need for hospitalization), serious (need for hospitalization) and mortal (dead at arrival or during resuscitation in Emergency Department) ${ }^{1}$. Sixty patients who were injured in 48 paragliding accident and brought to Gandaki Medical College Emergency Department were included in this study. Paragliding accidents victims who were treated and discharged from accidents site or in other hospital of Pokhara were excluded from this study.

\section{RESULTS}

Among 60 people who faced accidents and brought to hospital, four of them with severe multiple trauma were declared dead in the Emergency Department at the time of arrival. Fifty six patients were injured with varieties of injury. Forty eight (80\%) were males and $12(20 \%)$ were females. Their mean age was 35 years $(18-56)$. Sixteen $(26.6 \%)$ people were from Nepal and 44 (73.3\%) were tourists from other countries. Twelve were tandem flights and 36 were single (Solo) flights ended with an accident. Four were single flights of all 48 accidents that caused death. Twenty four patients were injured during tandem flights and 36 were injured during solo flights. Of all patients who were recorded, 20 were injured during take-off $(33.33 \%), 30$ were injured in mid-air $(50 \%)$, and $10(16.66 \%)$ were injured during landing (Table 1). Among 56 survived patients, 14 (25\%) were minor injuries and discharged from the Emergency Department after treatment for soft tissue trauma like abrasion or sprain. Twelve patients with poly-trauma (Including four chest injury, two abdominal injury with multiple bone fractures) and rest of the patients were admitted and treated/reffered/discharged.

In total 72 fractures were seen in survived injured case (Table 3). The most common were fractures around the foot and ankle $(n=20,27.77 \%)$, lumbar fractures $(n=12$, $16.6 \%)$, and wrist and hand fracture $(n=8,11.1 \%)$.
Table 1: Distribution of patient in different flight phase

\begin{tabular}{lc}
\hline Flight Phase & Numbers of injured \\
Take-off & 20 \\
Mid-air & 30 \\
Landing & 10 \\
Total & 60 \\
\hline
\end{tabular}

Table 2: Type of injury and number of cases

\begin{tabular}{llc}
\hline & Type of injury & Numbers of injured \\
1 & Polytrauma & 16 includes 4 deaths \\
2 & Isolated lower extremities injury & 16 \\
3 & Isolated upper extremities injury & 8 \\
4 & Isolated spine Fracture & 6 \\
5 & Soft tissue injury & 14 \\
& Total & 60 \\
\hline
\end{tabular}

Table 3: Number of fracture in different location

\begin{tabular}{lll}
\hline \multicolumn{1}{c}{ Location of fracture } & $\begin{array}{c}\text { Number of } \\
\text { cases }\end{array}$ \\
A $\quad$ Vertebra & 6 \\
& Thoracic & 12 \\
& Lumbar & 4 \\
& Pelvis & \\
B $\quad$ Lower extremities & 4 \\
& Femur & 6 \\
& Tibia & 20 \\
& Foot and ankle & \\
C $\quad$ Upper extremities & 4 \\
& Shoulder-humerus & 4 \\
& Elbow & 4 \\
forearm & 8 \\
\hline
\end{tabular}

Fig 1: Photograph of Compound fracture dislocation of right ankle in paragliding accident

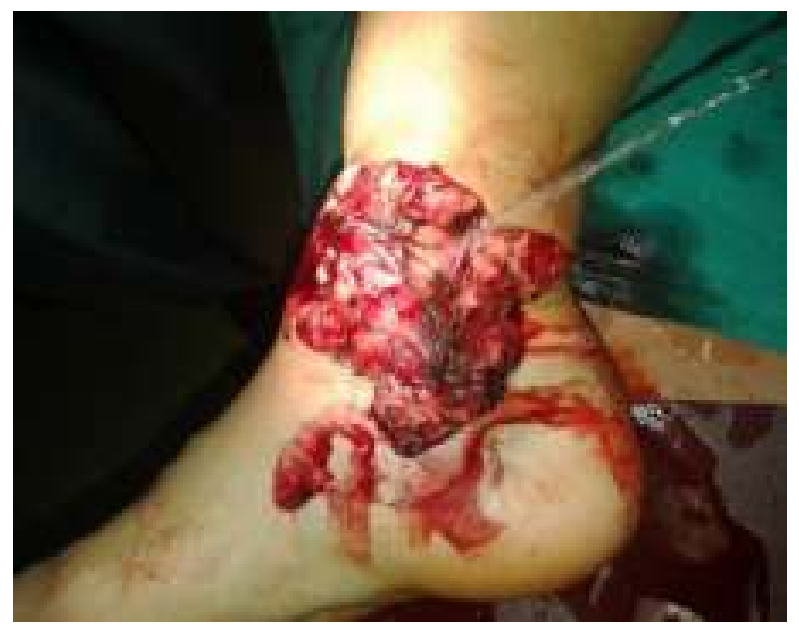




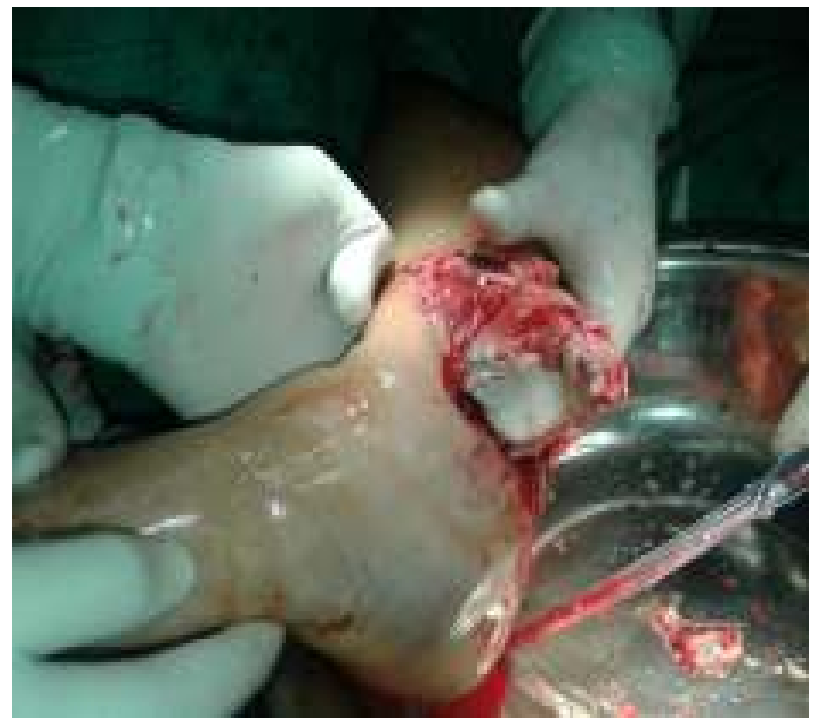

Fig 2: Radiograph of the same patient

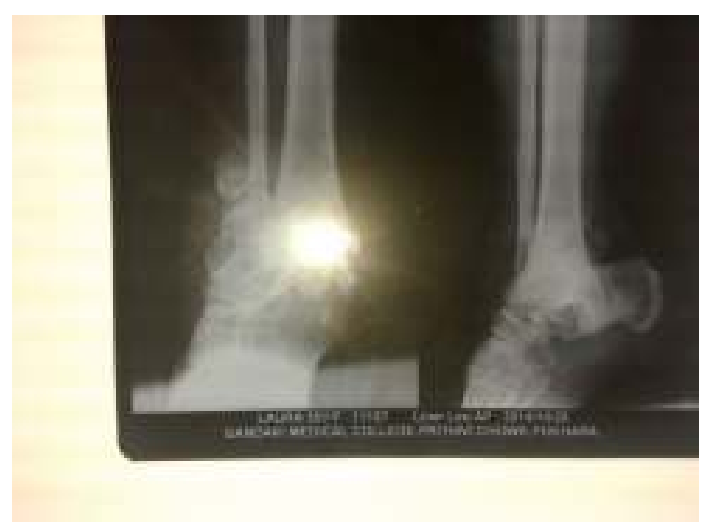

\section{DISCUSSION}

Paragliding is an adventurous aerial sport which is performed regularly in and around Pokhara. The growing popularity of paragliding sport has led to a steady increase in the number of associated injuries ${ }^{4,5}$. Certain studies ${ }^{6}$ have shown accidents cases due to paragliding were reduced in comparison to other adventurous aerial sports probably due to availability of protective measures and precautions.

In our series, $80 \%$ of patients were males and $20 \%$ were females. Gender distribution of our patients was consistent with that of Fasching et al reports about accidents in modern aerial and adventure sports ${ }^{4,7}$. The mean age of the patients was also consistent with that reported in the Gauler et al study ${ }^{2,8}$. In our study, $25 \%$ of survived patients had minor injury and they were discharged from the Emergency Department on the same day with or without medication. Among Orthopedic injury there were 72 fracture in survived patient in which lower extremity fracture rate was $40.2 \%(\mathrm{n}=30)$, which was similar to the Canbek et al study of $39.8 \%{ }^{1}$. and $(29 \%-56 \%)$ in other similar studies ${ }^{3,5}$. In this study, the paragliders did not use protective equipment except a simple helmet. Reports suggested that by refinement of pilot education, deliberate use of protective equipment, and better understanding of inherent aerodynamics of paragliding, the injury rates can be lowered ${ }^{3}$.

There was more number of solo flight accidents (36) than tandem flight (12). This may be due to in tandem flight pilots were more concerned about airbase condition during landing and take-off, maneuvering the flight according to the weather and avoids unnecessary acrobatic moves ${ }^{1}$. In this study, all mortality cases occurred in mid-air accident phase in solo flight which may be due to uncontrolled acrobatic manoeuver. The injury rate of paragliding was found to be lower than that of other adventure and extreme sports, but the accidents were more fatal in paragliding ${ }^{4}$. The most frequent detectable causes of the accidents were human errors and folding of the parachute during flight in bad weather conditions ${ }^{1,9}$.

The paragliding injury rate varies from 120 to 360 per 100,000 jumps in different studies ${ }^{4,10-12}$ but we could not calculate the rate as this was the single centre retrospective review. We could not collect all data from different paragliding company and even from the different hospital of this region, which is a major drawback and limitation of this study.

\section{CONCLUSION}

Lower limb especially foot and ankle injury were the commonest type of injury followed by spine fracture in paragliding accidents. To decrease the injury risk of extremities, proper protective equipment should be used by pilots and tandem paragliders. More studies should be conducted to obtain countrywide results and build a database about paragliding accidents.

\section{Acknowledgement}

We would like to express heartfelt thanks to all Emergency Department and Orthopedics ward staff of Gandaki Medical College Teaching Hospital for helping to gather data. 


\section{Conflict of Interest}

We declared that we have no competing interest and have not received any funding or benefit to conduct the study.

\section{REFERENCES}

1. Canbek U, Imerci A, Akgun U,Yesil M, Aydin A, Balci Y. Characteristics of injuries caused by paragliding accidents: A cross-sectional study. World J Emerg Med. 2015; 6(3): 221-224.

2. Gauler R, Moulin P, Koch HG, Wick L, Sauter B, Michel D, et al. Paragliding accidents with spinal cord injury: 10 years' experience at a single institution. Spine (Phila Pa 1976). 2006; 31: 11251130. [PubMed]

3. Schulze W, Richter J, Schulze B, Esenwein SA, Büttner-Janz K. Injury prophylaxis in paragliding. $\mathrm{Br}$ J Sports Med. 2002; 36: 365-369. [PMC free article] [PubMed]

4. Fasching G, Schippinger G, Pretscher R. Paragliding accidents in remote areas. Wilderness Environ Med. 1997; 8: 129-133. [PubMed]

5. W, Hesse B, Blatter G, Schmidtler B, Muhr G. Pattern of injuries and prophylaxis in paragliding. Sportverletz Sportschaden. 2000; 14: 41-49. [PubMed]
6. Amamilo SC, Samuel AW, Hesketh KT, Moynihan FJ. A prospective study of parachute injuries in civilians. J Bone Joint Surg Br. 1987; 69: 1719. [PubMed]

7. Rekand T. The epidemiology of injury in hanggliding and paragliding. Med Sport Sci. 2012; 58:44-56. [PubMed]

8. Ekerhovd KM, Novomesky F, Komarekova I, Strak L. Descriptive epidemiological study of fatal incidents and injury mechanisms among civilian sport parachutists in Norway from 1963 to 2008. Rom J Leg Med. 2013: 31-36.

9. Rekand T, Schaanning EE, Varga V, Schattel U, Gronning M. Spinal cord injuries among paragliders in Norway. Spinal Cord. 2008; 46: 412416. [PubMed]

10. Bohnsack M, Schröter E. Injury patterns and typical stress situations in paragliding. Orthopade. 2005; 34: 411-418. [PubMed]

11. Ekeland A. Injuries in military parachuting: a prospective study of 4499 jumps. Injury. 1997; 28: 219-222. [PubMed]

12. Ellitsgaard N. Parachuting injuries: a study of 110,000 sports jumps. Br J Sports Med. 1987; 21:13-17. [PMC free article] [PubMed] 